\title{
Downregulation of BCRP and anti-apoptotic proteins by proadifen (SKF-525A) is responsible for the enhanced mitoxantrone accumulation and toxicity in mitoxantrone-resistant human promyelocytic leukemia cells
}

\author{
LUCIA HILOVSKÁ, RASTISLAV JENDŽELOVSKÝ, \\ ZUZANA JENDŽELOVSKÁ, JÁN KOVAL' and PETER FEDOROČKO \\ Institute of Biology and Ecology, Department of Cellular Biology, \\ Pavol Jozef Šafárik University in Košice, SK-040 01 Košice, Slovak Republic
}

Received May 27, 2015; Accepted July 13, 2015

DOI: $10.3892 /$ ijo.2015.3116

\begin{abstract}
Multidrug resistance caused by the overexpression of $\mathrm{ABC}$ transporter proteins in cancer cells remains a major obstacle limiting chemotherapy efficacy. Drugs inhibiting these transporters have been shown to increase the anti-proliferative properties of chemotherapeutics. As we previously described, proadifen, a P450 monooxygenase inhibitor, might also be able to inhibit some $\mathrm{ABC}$ transporters, including breast cancer resistance protein (BCRP). Because mitoxantrone (MTX) is a strong BCRP substrate and is often used in the treatment of leukemia, we investigated the effect of $24 \mathrm{~h}$ proadifen pre-treatment on the cytotoxicity of MTX in leukemic cell lines that are sensitive to MTX (HL-60) and MTX-resistant ABCG2-overexpressing subclone (cBCRP). We show for the first time that proadifen is able to enhance the cytotoxic properties of MTX in cBCRP cells, particularly through the inhibition of BCRP expression and activity. This proadifen-MTX synergism was also mediated by the inhibition of various cellular proteins engaged in apoptosis, including Mc-1, Bcl-xL, survivin and activation of procaspase-3. Proadifen also decreased the expression of $\gamma \mathrm{H} 2 \mathrm{AX}$, which is involved in the recruitment of reparation proteins. Moreover, the inhibition of DNA damage repair proteins Ku86 and B23 after proadifen treatment indicate a possible role of proadifen in DNA repair blockage, thus suppressing the reparation rate of MTX-induced DSBs.
\end{abstract}

Correspondence to: Professor Peter Fedoročko, Institute of Biology and Ecology, Department of Cellular Biology, Pavol Jozef Šafárik University in Košice, Moyzesova 11, SK-040 01 Košice, Slovak Republic E-mail: peter.fedorocko@upjs.sk

Key words: proadifen, mitoxantrone, breast cancer resistance protein, leukemia cells

\section{Introduction}

Chemotherapy is one of the most common strategies in the treatment of cancer, although it is frequently unsuccessful due to the development of chemoresistance, and especially multidrug resistance (MDR). A number of mechanisms involved in the occurrence of MDR have been described, including the overexpression of one or more ATP binding cassette (ABC) transporter proteins that mediate the efflux of many clinically relevant drugs. More than $40 \mathrm{ABC}$ transporters have been identified so far, but just a few play a role in MDR, including the breast cancer resistance protein (BCRP/ABCG2). BCRP expression was detected in several different solid tumours (1-5), as well as in malignant hematopoietic and lymphoid cells (6). Moreover, BCRP is very often upregulated in cells undergoing mitoxantrone (MTX) treatment (7).

Several compounds have been shown to inhibit the efflux activity of $\mathrm{ABC}$ transporters, thereby increasing intracellular drug accumulation and sensitising cancer cells to therapy. It was previously reported that proadifen (SKF-525A), a well-known cytochrome P450 monooxygenase inhibitor, not only has antiproliferative potential in some cancer cell lines, but it is also able to inhibit BCRP and MRP1 transporter proteins (8). The exact molecular mechanism of proadifen antitumour action is not yet fully understood. However, it seems not to be dependent on the inhibitory activity against cytochrome P450 enzymes. In our previous study, we demonstrated the anti-proliferative and pro-apoptotic activity of proadifen in the HT-29 cancer cell line (9). Moreover, we revealed the ability of proadifen to increase the intracellular hypericin content in HT-29 cells most likely via the inhibition of BCRP and MRP1 transporters (8). Based on these results, we investigated the effect of proadifen pre-treatment on MTX toxicity. We examined not just the effect of proadifen and MTX on the expression of BCRP, but we were also interested in other molecular mechanisms involved in the possible antitumour activity of proadifen alone and in combination with MTX, such as the expression of anti- 
apoptotic proteins, proteins involved in the regulation of BCRP and proteins involved in the reparation of chemotherapeutic drug-induced DNA damage. Because MTX is a preferential and strong substrate of BCRP, MTX-sensitive HL-60 cell line and an MTX-resistant ABCG2-overexpressing subclone (here referred to as $\mathrm{cBCRP}$ ) were chosen as the experimental models.

\section{Materials and methods}

Cell culture. Human promyelocytic leukemia cell line HL-60 was purchased from the American Type Culture Collection (ATCC, Rockville, MD, USA) and its ABCG2-overexpressing subclone (here referred to as cBCRP) was kindly provided by Dr Balazs Sarkadi (Membrane Research Group, Hungarian Academy of Sciences, Budapest, Hungary) (10). Both cell lines were grown in complete RPMI-1640 medium (Gibco, Grand Island, NY, USA) supplemented with $10 \%$ fetal bovine serum (FBS; Gibco), 7.5\% $\mathrm{NaHCO}_{3}$ and antibiotics (penicillin $100 \mathrm{U} / \mathrm{ml}$, streptomycin $100 \mu \mathrm{g} / \mathrm{ml}$ and amphotericin $25 \mu \mathrm{g} / \mathrm{ml}$; Invitrogen, Carlsbad, CA, USA) at $37^{\circ} \mathrm{C}, 95 \%$ humidity and in atmosphere of $5 \% \mathrm{CO}_{2}$.

Reagents. Proadifen (SKF-525A; $\alpha$-phenyl- $\alpha$-propylbenzeneacetic acid 2-(diethylamino)ethylester; CAS no. 62-68-0; Sigma-Aldrich, St. Louis, MO, USA) and mitoxantrone dihydrochloride (MTX; 1,4-dihydroxy-5,8-bis[[2-[(2-hydroxyethyl) amino]-9,10-anthracenedione dihydrochloride; CAS no. 70476-82-3; HPLC grade, Sigma-Aldrich) stock solutions were prepared in distilled water and stored at $-20^{\circ} \mathrm{C}$ ). The concentrations of prepared stock solutions were 10 and $1 \mathrm{mM}$ for proadifen and MTX, respectively. Working solutions of both reagents were always freshly prepared before being added to the cultures. The final concentrations of distilled water did not influence the cytokinetic parameters. Because no significant differences in the response to distilled water were observed, these data are referred to as a control.

Experimental design. The cells were seeded in 96-well plates (MTT assay), in 6-well plates (flow cytometry analyses) or in 60-mm Petri dishes (western blotting, membrane-bound BCRP expression, RNA isolation) (all TPP, Trasadingen, Switzerland). Both cell lines were treated immediately after seeding (Fig. 1).

Experimental scheme A: For the determination of the $\mathrm{IC}_{20}$ values (20\% inhibitory concentration) of proadifen and MTX, MTT assays were performed 24, 48 and $72 \mathrm{~h}$ after proadifen and MTX addition ( 0 in the time schedule).

Experimental scheme B: Cells were pre-treated with proadifen for $24 \mathrm{~h}(-24 \mathrm{~h}$ in the time schedule) prior to MTX addition ( 0 in the time schedule). Changes in metabolic activity, mitochondrial membrane potential, cell death and cell cycle distribution were analysed 24 and $48 \mathrm{~h}$ after MTX treatment. Changes in the phosphorylation of the H2AX histone were analysed 2 and $24 \mathrm{~h}$ after MTX addition. Membrane-bound BCRP expression was examined $30 \mathrm{~min}, 1 \mathrm{~h}$ and $2 \mathrm{~h}$ after MTX treatment. BCRP mRNA level and the expression of selected proteins were detected $30 \mathrm{~min}, 1,2$ and $6 \mathrm{~h}$ after MTX addition.

MTT assay. To analyse the changes in the cell metabolic activity that occurred as the consequence of single and combined drug treatment, MTT assays were carried out as previously described (11). The results were evaluated as the percentage of the absorbance $(\lambda=584 \mathrm{~nm})$ of the untreated control. Proadifen and MTX $\mathrm{IC}_{20}$ values were extrapolated from an exponential fit to the metabolic activity data using OriginPro 8.5.0 SR1 software (OriginLab Corp., Northampton, MA, USA). To test the synergistic effect of proadifen pre-treatment on MTX action, MTT results were analysed using the Chou and Talalay (12) median-effect method with CalcuSyn software (Biosoft, Ferguson, MO, USA). The extent of interaction between proadifen and MTX was expressed through combination index $(\mathrm{CI})$ values.

Detection of mitochondrial membrane depolarisation. Cells were treated according to the experimental design (Fig. 1B), harvested, centrifuged, washed with HBSS and stained with $0.1 \mu \mathrm{M}$ TMRE (tetramethylrhodamine ethyl ester perchlorate; Sigma-Aldrich) in Hank's balanced salt solution (HBSS) for $20 \mathrm{~min}$ at RT in the dark. Thereafter, the cells were analysed ( $1 \times 10^{4}$ cells per sample) using a BD FACSCalibur flow cytometer (Becton-Dickinson, San Jose, CA, USA) with a 488-nm argon-ion excitation laser. Fluorescence was detected via a 585/42 band-pass filter (FL-2). The obtained results were analysed using FlowJo software (TreeStar Inc., Ashland, OR, USA) and are presented as the percentage of cells with dissipated MMP (mitochondrial membrane potential).

Analysis of viability and phosphatidylserine externalisation. Analysis of cell viability and phosphatidylserine externalisation was performed using the Apoptest ${ }^{\mathrm{TM}}$-FITC (Dako Denmark A/S, Glostrup, Denmark) according to the manufacturer's instructions. The cells were harvested at scheduled times (Fig. 1B), centrifuged, washed with HBSS and stained with Annexin V-FITC $(0.75 \mu \mathrm{g} / \mathrm{ml})$ in $1 \mathrm{X}$ binding buffer for $20 \mathrm{~min}$ at RT in the dark. Subsequently, the cells were stained with propidium iodide (PI; $1 \mu \mathrm{g} / \mathrm{ml}$ ) for $5 \mathrm{~min}$ and were analysed $\left(1 \times 10^{4}\right.$ cells per sample) using a BD FACSCalibur flow cytometer. Fluorescence was detected via a 530/30 nm band-pass filter (FL-1; Annexin V/FITC) and a $670 \mathrm{~nm}$ longpass filter (FL-3; PI). The results were evaluated using FlowJo software.

Cell cycle analysis. For the flow cytometric analysis of cell cycle distribution, cells were harvested at scheduled times (Fig. 1B), washed in cold phosphate-buffered saline (PBS), fixed in cold $70 \%$ ethanol and kept at $-20^{\circ} \mathrm{C}$ overnight. Prior to analysis, the cells were washed twice in PBS, resuspended in staining buffer $(0.1 \%$ Triton X-100, $0.137 \mathrm{mg} / \mathrm{ml}$ ribonuclease A and $0.02 \mathrm{mg} / \mathrm{ml} \mathrm{PI}$ ), incubated for $30 \mathrm{~min}$ at RT in the dark and analysed using a BD FACSCalibur flow cytometer $\left(2 \times 10^{4}\right.$ cells per sample). Fluorescence was detected via a 585/42 nm band-pass filter (FL-2). ModFit 3.0 software (Verity Software House, Topsham, ME, USA) was used to generate DNA content frequency histograms and quantify the number of cells in the individual cell cycle phases (G0/G1, S and G2/M).

Intracellular accumulation of MTX. The cells were pre-treated with proadifen for $24 \mathrm{~h}$. Immediately after incubation, the cells were harvested and resuspended in HBSS. Afterwards, MTX was added to the cells and its intracellular accumula- 


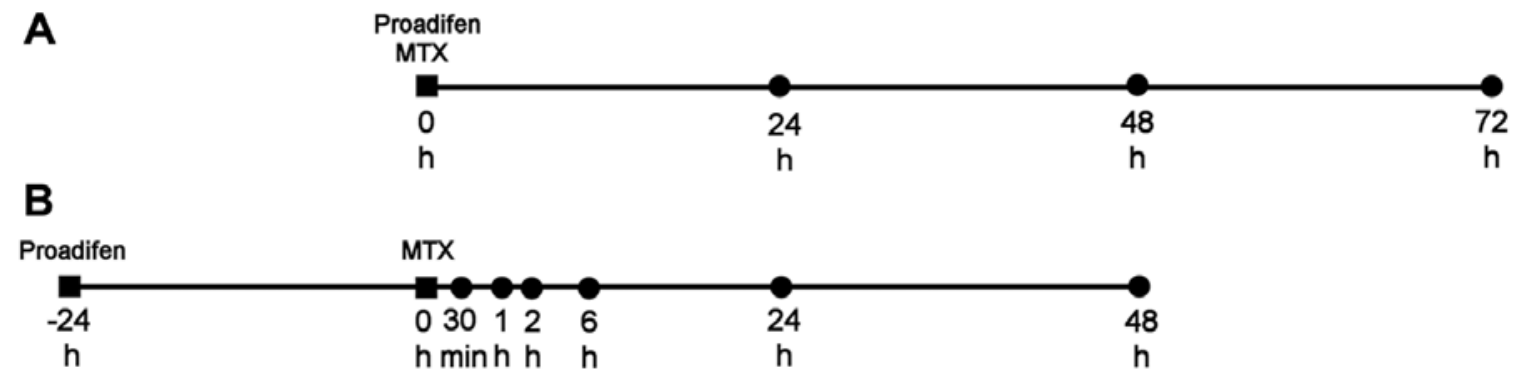

Figure 1. Experimental design. (A) Analyses of single drug treatment; (B) Analyses of combined drug treatment.

tion was detected continuously for the duration of $45 \mathrm{~min}$. The measurement was performed by BD FACSAria II SORP (Becton-Dickinson) using excitation with a $640 \mathrm{~nm}$ laser and emission acquisition in an Alexa Fluor 700 (DM685LP-710/50) channel.

Cell surface expression of BCRP. For the flow cytometry assay that was intended to detect cell surface expression of BCRP, cells $\left(3 \times 10^{5}\right)$ were harvested at scheduled time-points (Fig. 1B), washed in staining buffer (HBSS with 5\% FBS) and incubated with FITC-conjugated anti-BCRP primary antibody [ABCG2 (5D3) FITC, 1:100, sc-18841 FITC, Santa Cruz Biotechnology Inc.] or the FITC-conjugated mouse IgG2b as an isotype control (normal mouse IgG2b-FITC, 1:100, sc-2857, Santa Cruz Biotechnology Inc.) for $30 \mathrm{~min}$ at RT in the dark. The cells were then washed in HBSS and analysed on a BD FACSCalibur flow cytometer $\left(2 \times 10^{4}\right.$ cells per sample). The obtained data were analysed using FlowJo software. Cell surface BCRP was expressed as a ratio of the median fluorescence of ABCG2 (5D3) and of the IgG2b isotype control.

Histone H2AX phosphorylation. Flow cytometric analysis of the histone H2AX phosphorylation on Ser139 ( $\gamma \mathrm{H} 2 \mathrm{AX})$ was performed to examine possible changes in MTX-mediated DNA double strand breaks (DSBs), as previously described (13). Fluorescence intensity was detected using a BD FACSCalibur flow cytometer via a 530/30 nm band-pass filter (FL-1) and the results were analysed using FlowJo software. The expression of $\gamma \mathrm{H} 2 \mathrm{AX}$ was expressed as a ratio of the median fluorescence of Alexa Fluor ${ }^{\circledR} 488$ Mouse anti-H2AX (pS139) (cat. no. 560445, BD Biosciences) and of Alexa Fluor 488 Mouse IgG1 $\kappa$ Isotype Control (cat. no. 557782, BD Biosciences). The results are presented as the fold of untreated control.

Western blot analysis. For detection of the expression of selected proteins, cells were treated in line with the experimental design (Fig. 1B). Western blot analysis was performed, as previously described (13). The blots were incubated overnight at $4^{\circ} \mathrm{C}$ with the specific primary antibodies: polyclonal rabbit anti-human survivin (\#2803, 1:500), monoclonal rabbit anti-human Bcl-xL (\#2764, 1:1,000), monoclonal rabbit antihuman p-Akt (Ser473) (\#4060, 1:1,000), polyclonal rabbit anti-human Akt (\#9272, 1:1,000) (all from Cell Signaling Technology, Danvers, MA, USA), monoclonal mouse antihuman Bcl-2 (sc-7382, 1:250), monoclonal mouse anti-human caspase-3 (sc-7272, 1:500), mouse monoclonal anti-human
B23 (sc-32256, 1:500), mouse monoclonal anti-human BCRP (sc-58222, 1:400), monoclonal mouse anti-human Ku-86 (sc-5280, 1:500), monoclonal mouse anti-human E2F1 (sc-251, 1:250) (all from Santa Cruz Biotechnology, Santa Cruz, CA, USA), polyclonal rabbit anti-human Mcl-1 (M8484, 1:1,000) (Sigma-Aldrich). After $30 \mathrm{~min}$ of washing in TBS, the membranes were incubated with appropriate horseradish peroxidase-conjugated (HRP) secondary antibodies for $1 \mathrm{~h}$ at RT (goat anti-rabbit IgG-HRP, 1:5,000, \#31461; goat antimouse IgG-HRP, 1:5,000, \#31436, Pierce Biotechnology, Rockford, IL, USA). Antibody reactivity was detected with Pierce ECL Western Blotting Substrate (Pierce Biotechnology) and was visualised on medical X-ray films (Agfa HealthCare $\mathrm{NV}$, Mortsel, Belgium). Equal sample loading was verified by immunodetection of $\beta$-actin (A5441, monoclonal, mouse, Sigma-Aldrich). The densitometry of proteins was evaluated using ImageJ software (NIH, Bethesda, MD, USA). Relative protein levels were normalised to the expression of $\beta$-actin.

RNA extraction and semiquantitative RT-PCR. In order to evaluate $A B C G 2$ expression in the HL-60 and cBCRP cell lines, cells were seeded and treated according to the experimental schedule (Fig. 1B). Total RNA isolation, the evaluation of RNA concentration, purity, integrity and the whole RT-PCR procedure was performed, as previously described (13). The samples (50 ng cDNA) were subjected to PCR amplifications with primers specific for $A B C G 2$ (F, 5'-GGCCATAGCAGC AGGTCAGAGTG-3'; R, 5'-TGCAAAGCCGTAAATCCATA TCGTG-3'). As an internal loading control, GAPDH (F, 5'-ATG GGGAAGGTGAAGGTCGGAGTC-3'; R, 5'-CTCGCTCCT GGAAGATGGTGATGG-3') and also ACTB genes (F, 5'-GAT CCGCCGCCCGTCCACAC-3'; R, 5'-TTGCACATGCCGG AGCCGTTG-3') were used. Each PCR mixture contained cDNA; deoxynucleoside triphosphates (dNTP Mix, Fermentas, Thermo Fisher Scientific, Vilnius, Lithuania) at a concentration of $200 \mu \mathrm{M} ; 0.2 \mu \mathrm{M}$ of each primer; and 1 unit of BioTherm $A^{\text {TM }}$ Hot Start Taq DNA Polymerase (GeneCraft Köln, Germany) in a total volume of $25 \mu \mathrm{l}$. The PCR was performed on a Mastercycler pro S (Eppendorf, Hamburg, Germany), and the reaction conditions were as follows: initial denaturation at $94^{\circ} \mathrm{C}$ for $2 \mathrm{~min}$, followed by numerous cycles (20 cycles for $A B C G 2$ and $G A P D H, 25$ cycles for $A C T B$ ) of denaturation at $94^{\circ} \mathrm{C}$ for $30 \mathrm{sec}$, annealing at the annealing temperature for $30 \mathrm{sec}$ and elongation at $72^{\circ} \mathrm{C}$ for $45 \mathrm{sec}$, with a final extension at $72^{\circ} \mathrm{C}$ for $10 \mathrm{~min}$. The number of cycles was adjusted to allow detection in the linear range. The densito- 
Table I. The $\mathrm{IC}_{20}$ of proadifen and MTX in HL-60 and cBCRP cells. ${ }^{\mathrm{a}}$

\begin{tabular}{|c|c|c|c|c|c|c|}
\hline & \multirow[b]{2}{*}{$24 \mathrm{~h}$} & \multirow{2}{*}{$\frac{\text { HL-60 }}{48 \mathrm{~h}}$} & \multirow[b]{2}{*}{$72 \mathrm{~h}$} & \multicolumn{3}{|c|}{ cBCRP } \\
\hline & & & & $24 \mathrm{~h}$ & $48 \mathrm{~h}$ & $72 \mathrm{~h}$ \\
\hline \multicolumn{7}{|l|}{ Proadifen } \\
\hline $\mathrm{IC}_{20}(\mu \mathrm{M})$ & 11.28 & 6.95 & 5.51 & 40.49 & 37.19 & 30.74 \\
\hline \multicolumn{7}{|l|}{ MTX } \\
\hline $\mathrm{IC}_{20}(\mu \mathrm{M})$ & 0.029 & 0.011 & 0.002 & 3.68 & 1.53 & 0.36 \\
\hline
\end{tabular}

${ }^{\text {aEstimated }} \mathrm{IC}_{20}$ values were derived from mean metabolic activity values of at least three independent experiments.
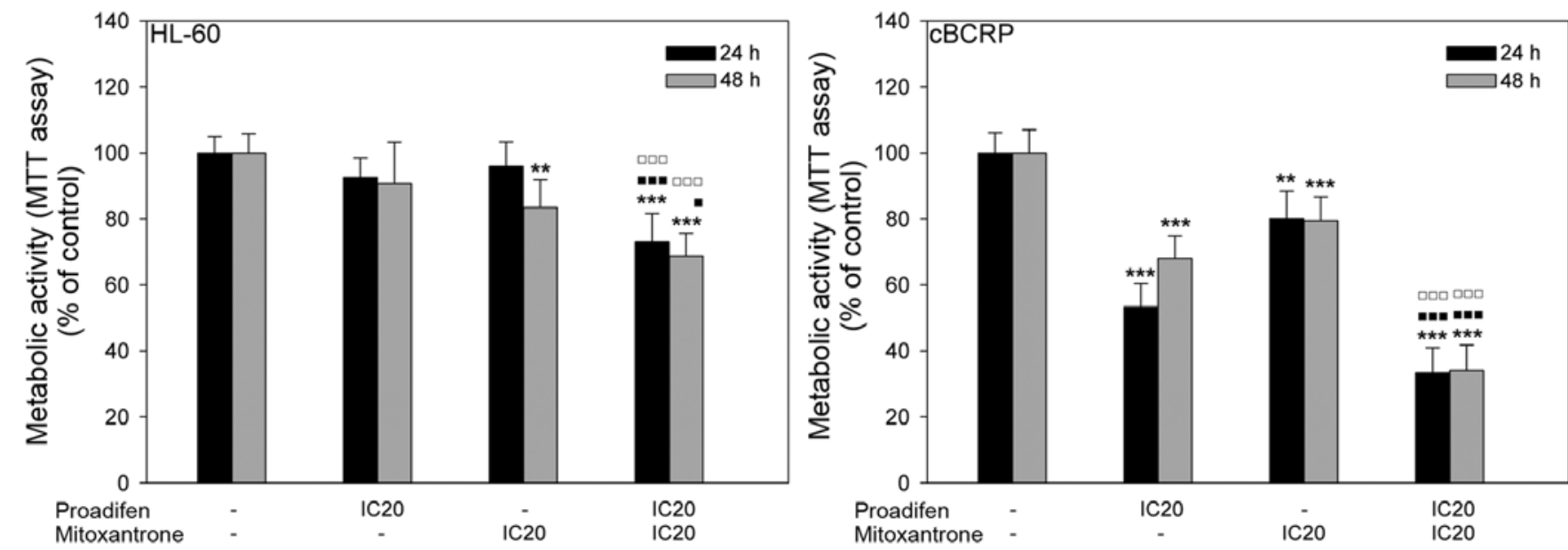

Figure 2. Changes in cell metabolic activity. Effects of proadifen, MTX and their combination on the metabolic activity of HL-60 and cBCRP cells. The results are expressed as the mean values $\pm \mathrm{SD}$ of at least three independent experiments. The groups treated with proadifen alone $\left(\mathrm{IC}_{20} \mathrm{in} \mathrm{HL}-60\right.$ equals $6.95 \mu \mathrm{M} / 24 \mathrm{~h}$ and $5.51 \mu \mathrm{M} / 48 \mathrm{~h} ; \mathrm{IC}_{20}$ in cBCRP equals $37.19 \mu \mathrm{M} / 24 \mathrm{~h}$ and $\left.30.74 \mu \mathrm{M} / 48 \mathrm{~h}\right)$ and MTX alone $\left(\mathrm{IC}_{20}\right.$ in HL-60 equals $0.029 \mu \mathrm{M} / 24 \mathrm{~h}$ and $0.011 \mu \mathrm{M} / 48 \mathrm{~h} ; \mathrm{IC}_{20}$ in cBCRP equals $3.68 \mu \mathrm{M} / 24 \mathrm{~h}$ and $1.53 \mu \mathrm{M} / 48 \mathrm{~h}$ ) were compared to the untreated control ( $\left(* * \mathrm{p}<0.01,{ }^{* * * *} \mathrm{p}<0.001\right)$. The groups given combined treatment were compared to proadifen alone $\left({ }^{\square} \mathrm{p}<0.001\right)$ and MTX alone $\left(\boldsymbol{\mathrm { p }}<0.05, \boldsymbol{- "}_{\mathrm{p}}^{\mathrm{p}}<0.001\right)$.

metry analysis of the PCR products was evaluated using Image software and the $A B C G 2$ levels were normalised to $G A P D H$.

Statistical analysis. The results were analysed using a one-way ANOVA with Tukey's post-test or t-test and are expressed as the mean \pm standard deviation (SD) of at least three independent experiments. Significance levels are indicated in the legend for each figure.

\section{Results}

Effects of proadifen and MTX on cell metabolic activity. The metabolic activity was assessed after exposure of HL-60 and cBCRP cells to $0-50 \mu \mathrm{M}$ proadifen and 0-20 $\mu \mathrm{M}$ MTX. Proadifen and MTX showed a time- and dose-dependent inhibitory effect on both cell lines, with a more pronounced effect on sensitive HL-60 cells (data not shown). $\mathrm{IC}_{20}$ values for proadifen, as well as for MTX (Table I), were evaluated for further combined drug treatment experiments.

To determine the impact of proadifen on MTX action, cells were pre-treated with proadifen for $24 \mathrm{~h}$. The inhibitory effect of MTX on cell metabolic activity was potentiated by proad- ifen in both cell lines. A much stronger effect was observed in resistant cBCRP cells, where the metabolic activity significantly decreased in the experimental group administered the combined treatment compared to the group treated with MTX alone (Fig. 2).

Based on these results, proadifen-MTX combination index (CI) values were evaluated using CalcuSyn software (Table II) and synergism was revealed in both cell lines.

Proadifen effect on MTX cytotoxicity. To determine whether proadifen-MTX synergism arising from the MTT assay may reflect the impact of proadifen on MTX cytotoxicity, various cell death parameters were analysed. Changes in mitochondrial membrane depolarisation revealed different effects in sensitive HL-60 and resistant cBCRP cells. In the resistant cell line proadifen alone and MTX alone significantly increased the percentage of cells with dissipated mitochondrial membrane potential (MMP) compared to the untreated control. Additionally, the cytotoxic effect of MTX was more pronounced after proadifen pre-treatment, particularly at $48 \mathrm{~h}$ after MTX addition (Fig. 3). In contrast, proadifen did not influence MMP in HL-60 cells either alone or combined with 
Table II. Combination index (CI) values of proadifen-MTX mutual combinations. ${ }^{a}$

\begin{tabular}{lccll}
\hline & Proadifen $(\mu \mathrm{M})$ & Mitoxantrone $(\mu \mathrm{M})$ & CI & CalcuSyn effect \\
\hline HL-60 & & & & \\
$24 \mathrm{~h}$ & 5 & 0.05 & 0.630 & Synergism \\
& 5 & 0.01 & 0.965 & Nearly additive \\
$48 \mathrm{~h}$ & 5 & 0.01 & 0.744 & Moderate synergism \\
$\mathrm{BCRP}$ & & & \\
$24 \mathrm{~h}$ & 35 & 5 & 0.780 & Moderate synergism \\
& 40 & 5 & 0.855 & Slight synergism \\
$48 \mathrm{~h}$ & 30 & 1 & 0.886 & Slight synergism \\
\hline
\end{tabular}

${ }^{a} \mathrm{CI}$ values were calculated from mean cell metabolic activity of at least three independent experiments using the CalcuSyn program.
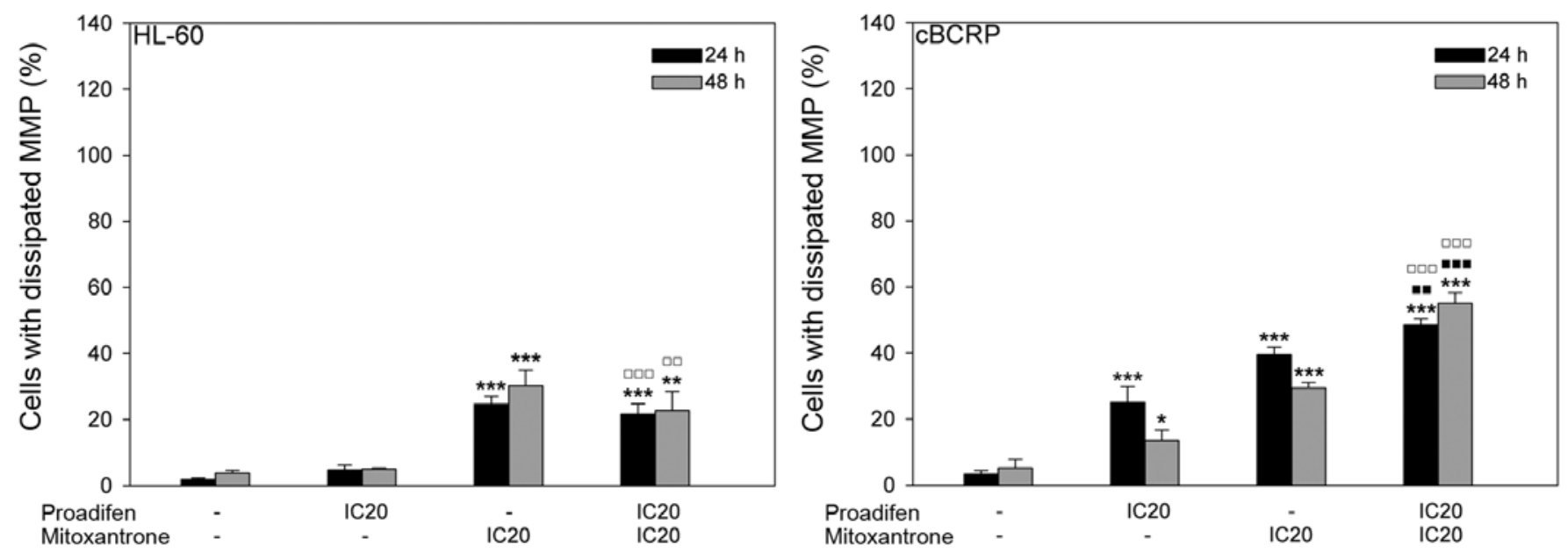

Figure 3. Changes in the percentage of cells with dissipated mitochondrial membrane potential (MMP). Effects of proadifen, MTX and their combination. The results are expressed as the mean values \pm SD of at least three independent experiments. The groups treated with proadifen alone $\left(\mathrm{IC}_{20}\right.$ in $\mathrm{HL}-60$ equals $6.95 \mu \mathrm{M} / 24 \mathrm{~h}$ and $5.51 \mu \mathrm{M} / 48 \mathrm{~h} ; \mathrm{IC}_{20}$ in cBCRP equals $37.19 \mu \mathrm{M} / 24 \mathrm{~h}$ and $30.74 \mu \mathrm{M} / 48 \mathrm{~h}$ ) and MTX alone (IC ${ }_{20}$ in HL-60 equals $0.029 \mu \mathrm{M} / 24 \mathrm{~h}$ and $0.011 \mu \mathrm{M} / 48 \mathrm{~h}$; $\mathrm{IC}_{20}$ in cBCRP equals $3.68 \mu \mathrm{M} / 24 \mathrm{~h}$ and $\left.1.53 \mu \mathrm{M} / 48 \mathrm{~h}\right)$ were compared to the untreated control $\left({ }^{*} \mathrm{p}<0.05,{ }^{* *} \mathrm{p}<0.01,{ }^{* * *} \mathrm{p}<0.001\right)$. The groups given combined treatment were compared to proadifen alone $\left({ }^{\square} \mathrm{p}<0.01,{ }^{\square} \mathrm{p}<0.001\right)$ and MTX alone $\left(\boldsymbol{"}^{\mathrm{p}}<0.01,{ }^{\mathrm{M}} \mathrm{p}<0.001\right)$.

MTX. The cytotoxic action of MTX was slightly reduced by proadifen in the HL-60 cell line (Fig. 3).

Consistent with the results of the MMP analysis, Annexin V-FITC/PI double staining revealed no effect of proadifen on MTX cytotoxicity in HL-60 cells (Table III). In the case of the cBCRP cell line, proadifen markedly potentiated MTX-induced cell death. Proadifen significantly increased the percentage of cells in the later stages of apoptosis $\left(\right.$ Annexin $\left.\mathrm{V}^{+} / \mathrm{PI}^{+}\right) 24$ and $48 \mathrm{~h}$ after MTX treatment. Moreover, $48 \mathrm{~h}$ after MTX addition, proadifen even caused massive accumulation of the cells in the early stages of programmed cell death $\left(\right.$ Annexin $\left.\mathrm{V}^{+} / \mathrm{PI}^{\mathrm{I}}\right)$.

Effects of proadifen, MTX and combined treatment on cell cycle distribution. Cell cycle distribution was affected by both drugs (Fig. 4). Proadifen alone caused a significant accumulation of cBCRP cells in the G0/G1 phase $24 \mathrm{~h}$ after treatment. Simultaneously, a reduction of the cells in the S-phase was observed. In the case of the HL-60 cell line, proadifen alone caused the opposite effect. On the other hand, MTX alone markedly affected cell cycle progression in both cell lines, leading to a massive $\mathrm{G} 2 / \mathrm{M}$ arrest and reduction of cells in the G0/G1 phase. The MTX-induced accumulation of HL-60 and cBCRP cells in the G2/M phase was even stronger $48 \mathrm{~h}$ after treatment. The effect of proadifen pre-treatment on MTX cytostatic action was observed only in resistant cBCRP cells. Proadifen caused cell cycle redistribution by the significant attenuation of MTX-mediated G2/M arrest and increased accumulation of cBCRP cells in the G0/G1 phase (Fig. 4).

Effects of proadifen, MTX and combined treatment on histone $H 2 A X$ phosphorylation. To determine whether the cytotoxic effect of MTX was correlated with its ability to cause DSBs, the phosphorylation of histone H2AX on Ser139 $(\gamma \mathrm{H} 2 \mathrm{AX})$ was analysed. MTX alone elevated the expression of $\gamma \mathrm{H} 2 \mathrm{AX}$, especially in the sensitive cell line. The effect of proadifen on the $\gamma \mathrm{H} 2 \mathrm{AX}$ level was cell line-dependent, leading to a slight decrease in $\gamma \mathrm{H} 2 \mathrm{AX}$ expression in cBCRP cells. However, no changes in the phosphorylation of H2AX in the HL-60 cells 
Table III. Analysis of cell death. ${ }^{\mathrm{a}}$

Annexin $\mathrm{V}^{+} / \mathrm{PI}^{-}$

Annexin $\mathrm{V}^{-} / \mathrm{PI}^{+}$

Annexin $\mathrm{V}^{+} / \mathrm{PI}^{+}$

HL-60

$24 \mathrm{~h}$

$\begin{array}{ll}\text { Control } & 0.47 \pm 0.16 \\ \text { Proadifen } & 0.64 \pm 0.21 \\ \text { MTX } & 1.21 \pm 0.59 \\ \text { Proadifen + MTX } & 0.89 \pm 0.35\end{array}$

$48 \mathrm{~h}$

$\begin{array}{ll}\text { Control } & 0.44 \pm 0.17 \\ \text { Proadifen } & 0.57 \pm 0.33 \\ \text { MTX } & 0.56 \pm 0.31 \\ \text { Proadifen + MTX } & 0.42 \pm 0.22\end{array}$

cBCRP

$24 \mathrm{~h}$

$\begin{array}{ll}\text { Control } & 0.36 \pm 0.04 \\ \text { Proadifen } & 0.53 \pm 0.26 \\ \text { MTX } & 7.89 \pm 0.76^{\mathrm{d}} \\ \text { Proadifen + MTX } & 1.79 \pm 0.13^{\mathrm{b}, \mathrm{i}}\end{array}$

$48 \mathrm{~h}$

\begin{tabular}{lccr} 
Control & $0.74 \pm 0.18$ & $0.72 \pm 0.08$ & $3.11 \pm 0.71$ \\
Proadifen & $0.79 \pm 0.05$ & $1.15 \pm 0.05$ & $5.37 \pm 1.70$ \\
MTX & $0.71 \pm 0.20$ & $6.30 \pm 0.35^{\mathrm{c}}$ & $12.97 \pm 3.63^{\mathrm{b}}$ \\
Proadifen + MTX & $14.26 \pm 2.23^{\mathrm{d}, \mathrm{g}, \mathrm{i}}$ & $6.41 \pm 1.99^{\mathrm{c}, \mathrm{f}}$ & $31.39 \pm 3.87^{\mathrm{d}, \mathrm{g}, \mathrm{i}}$ \\
\hline
\end{tabular}

${ }^{a}$ Effects of proadifen, MTX and their mutual combination on phosphatidylserine externalisation (Annexin V) and viability (PI). The results are expressed as the mean values $\pm \mathrm{SD}$ of at least three independent experiments. The groups treated with proadifen alone $\left(\mathrm{IC}_{20}\right.$ in $\mathrm{HL}-60$ equals $6.95 \mu \mathrm{M} / 24 \mathrm{~h}$ and $5.51 \mu \mathrm{M} / 48 \mathrm{~h} ; \mathrm{IC}_{20}$ in cBCRP equals $37.19 \mu \mathrm{M} / 24 \mathrm{~h}$ and $30.74 \mu \mathrm{M} / 48 \mathrm{~h}$ ) and MTX alone (IC 20 in HL-60 equals $0.029 \mu \mathrm{M} / 24 \mathrm{~h}$ and $0.011 \mu \mathrm{M} / 48 \mathrm{~h} ; \mathrm{IC}_{20}$ in cBCRP equals $3.68 \mu \mathrm{M} / 24 \mathrm{~h}$ and $\left.1.53 \mu \mathrm{M} / 48 \mathrm{~h}\right)$ were compared to the untreated control $\left({ }^{\mathrm{b}} \mathrm{p}<0.05\right.$, $\left.{ }^{c} \mathrm{p}<0.01,{ }^{d} \mathrm{p}<0.001\right)$. The groups given combined treatment were compared to proadifen alone $\left({ }^{e} \mathrm{p}<0.05,{ }^{\mathrm{f}} \mathrm{p}<0.01,{ }^{g} \mathrm{p}<0.001\right)$ and $\mathrm{MTX}$ alone $\left({ }^{\mathrm{h}} \mathrm{p}<0.05,{ }^{\mathrm{i}} \mathrm{p}<0.001\right)$.

were detected. Interestingly, pre-treatment of cBCRP cells with proadifen markedly decreased the MTX-induced $\gamma \mathrm{H} 2 \mathrm{AX}$ expression, with a more significant effect $24 \mathrm{~h}$ after MTX addition (Fig. 5A).

Proadifen effect on BCRP expression and activity. The analysis of MTX accumulation in HL-60 and cBCRP cells was performed to verify the possible inhibitory effect of proadifen on the BCRP transporter (Fig. 6A). Changes in MTX fluorescence were measured continuously over time (duration of $45 \mathrm{~min}$ ). In the case of the ABCG2-overexpressing cBCRP cell line, $24 \mathrm{~h}$ proadifen pre-treatment led to an increase in the intracellular MTX level. On the other hand, proadifen slightly decreased the intracellular accumulation of MTX in the HL-60 cells (Fig. 6A).

To determine whether the changes in the increased intracellular accumulation of MTX after combined drug treatment were associated with decreased expression of BCRP, whole cell protein levels, as well as cell surface expression of BCRP, were detected. In the case of the BCRP transporter, no protein levels were detected in the HL-60 cells (Fig. 6B). Simultaneously, $\mathrm{BCRP}$ overexpression was confirmed in the cBCRP cell line. The level of this transporter protein was decreased by proadifen and by the combined drug treatment, particularly $6 \mathrm{~h}$ after MTX addition (Fig. 6B). The 5D3 antibody recognises an extracellular epitope of BCRP transporter protein. In HL-60 cells, no changes in membrane-bound BCRP were detected. However, proadifen alone, as well as in combined treatment, led to a slight reduction in the expression of cell surface BCRP in resistant cBCRP cells (Fig. 6C).

To verify whether proadifen-mediated reduction of the BCRP protein level correlated with its mRNA content, semi-quantitative RT-PCR was performed (Fig. 6D). Marked differences in BCRP ( $A B C G 2)$ expression between the cell lines were confirmed. Although BCRP mRNA was detectable in HL-60 cells, its content was very low compared to cBCRP cells. Considering the impact of proadifen on the $A B C G 2$ mRNA level, no downregulation was observed, except for the later time-point $(6 \mathrm{~h})$ in the case of the cBCRP experimental group given the combined treatment (Fig. 6D). Interestingly, 

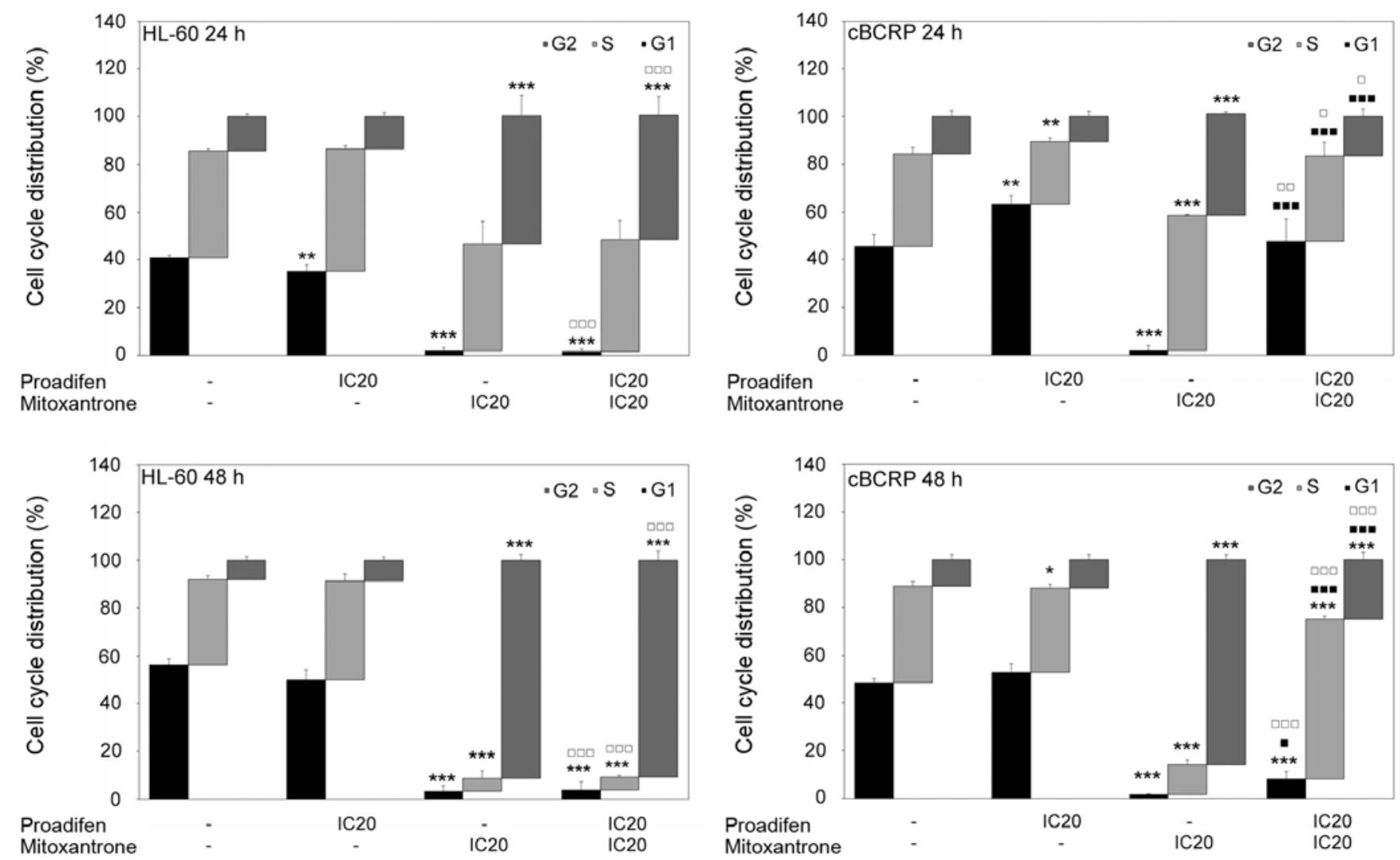

Figure 4. Changes in cell cycle distribution. Effects of proadifen, MTX and their combination on the distribution of the cell cycle. The results are expressed as the mean values $\pm \mathrm{SD}$ of at least three independent experiments. The groups treated with proadifen alone (IC 20 in $\mathrm{HL}-60$ equals $6.95 \mu \mathrm{M} / 24 \mathrm{~h}$ and $5.51 \mu \mathrm{M} / 48 \mathrm{~h} ;$ $\mathrm{IC}_{20}$ in cBCRP equals $37.19 \mu \mathrm{M} / 24 \mathrm{~h}$ and $\left.30.74 \mu \mathrm{M} / 48 \mathrm{~h}\right)$ and MTX alone $\left(\mathrm{IC}_{20}\right.$ in HL-60 equals $0.029 \mu \mathrm{M} / 24 \mathrm{~h}$ and $0.011 \mu \mathrm{M} / 48 \mathrm{~h}$; IC 20 in $\mathrm{cBCRP}$ equals $3.68 \mu \mathrm{M} / 24 \mathrm{~h}$ and $1.53 \mu \mathrm{M} / 48 \mathrm{~h})$ were compared to the untreated control $\left({ }^{*} \mathrm{p}<0.05,{ }^{* *} \mathrm{p}<0.01,{ }^{* * * *} \mathrm{p}<0.001\right)$. The groups given the combined treatment were

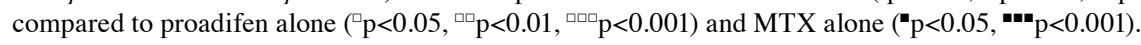

proadifen treatment decreased the mRNA content for internal loading control GAPDH in cBCRP cells, despite the fact that equal amounts of mRNA were used for cDNA synthesis. This effect was confirmed in $A C T B$, another housekeeping gene, even though no changes in $\beta$-actin protein levels were detected.

Proadifen, MTX and combined treatment-mediated changes in protein levels. To determine whether the changes in cytotoxicity of the combined drug treatment were associated with altered expression of anti-apoptotic proteins, proteins engaged in DNA damage repair or proteins regulating the expression of BCRP transporter, western blot analysis was performed at early time-points after the MTX addition (30 min, 1, 2 and 6 h) (Fig. 7).

In cBCRP cells, proadifen alone and combined with MTX markedly downregulated several anti-apoptotic proteins, especially Mcl-1, Bcl-xL and survivin (Fig. 7). On the other hand, proadifen, MTX and their combination increased the level of anti-apoptotic protein Bcl-2 above that of the untreated control (Fig. 7). This effect was most pronounced $6 \mathrm{~h}$ after the MTX addition. Moreover, single and combined drug treatments led to the activation of procaspase-3 (Fig. 7).

The reduction of transcription factor E2F1 that is potentially involved in the regulation of BCRP expression was observed, except for one time-point (2 h) (Fig. 8). However, protein levels of pAkt, which may also be engaged in the regulation of BCRP activity and expression, were increased after single and combined drug treatment, except for the latest timepoint (Fig. 8). On the other hand, we detected downregulated protein levels of Akt (Fig. 8).

Proteins involved in DSB repair were also investigated (Fig.5B). We observed slightly elevated levels of Ku86 (XRCC5) in cBCRP cells compared to HL-60 cells. Proadifen alone and in combination with MTX downregulated the expression of both Ku86 and B23 (NPM1). The strongest effect of single and combined drug treatment was observed at the third time-point $(2 \mathrm{~h})$ in the case of Ku86. On the other hand, the levels of B23 were markedly decreased $1 \mathrm{~h}$ and $6 \mathrm{~h}$ after MTX treatment.

\section{Discussion}

Cancer cell chemoresistance remains a major obstacle to successful therapy. Great effort has been made to identify various agents that could sensitise cancer cells to treatment, thereby improving chemotherapy outcome. Proadifen (SKF-525A), an inhibitor of cytochrome P450 monooxygenases (P450), is a drug approved by the US Food and Drug Administration (14) and is used as a local anaesthetic (15). Additionally, anti-proliferative properties of proadifen on various cancer cell lines have also been demonstrated (9). Moreover, proadifen has been shown to potentiate the efficiency 
A
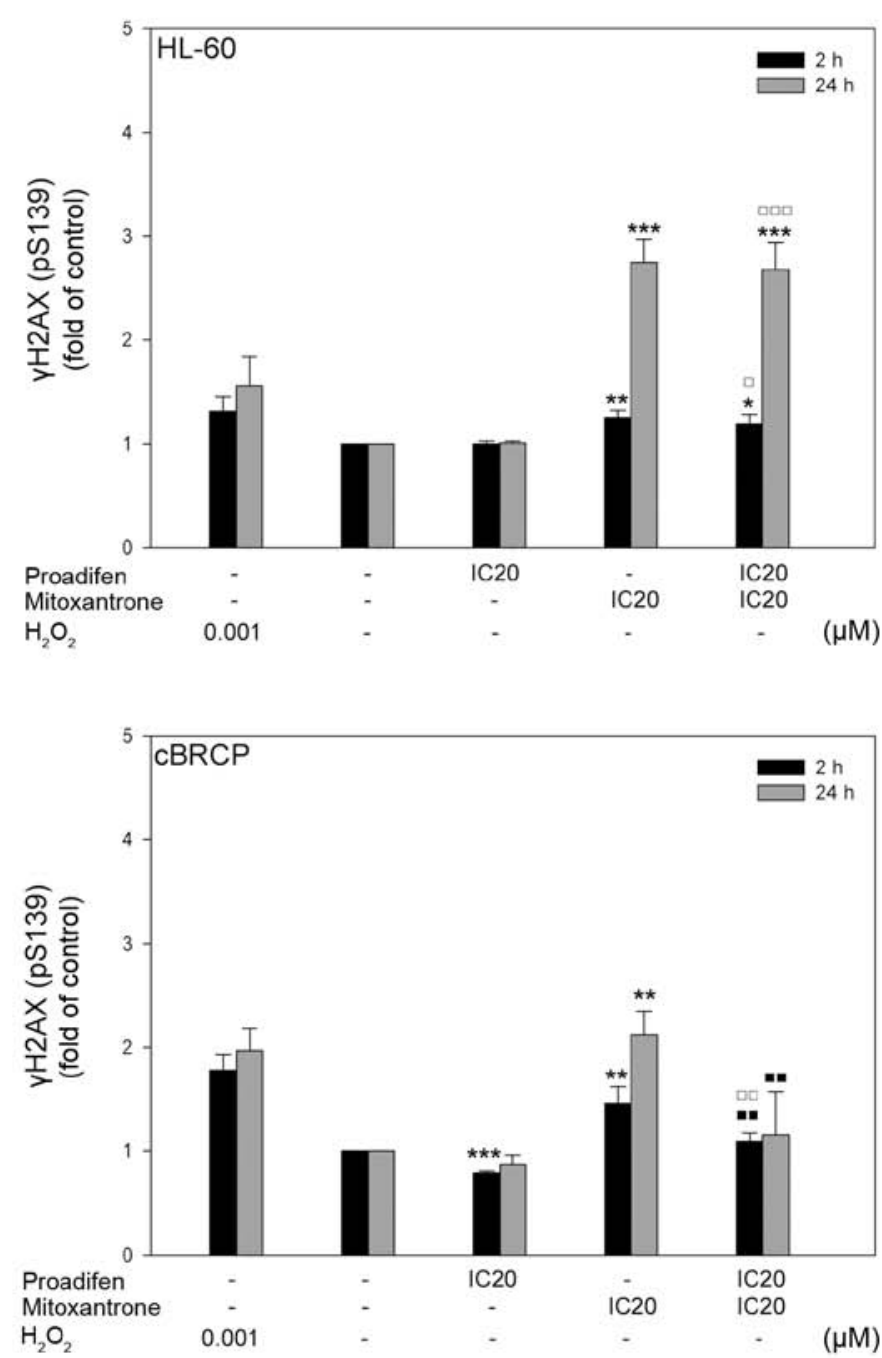

B
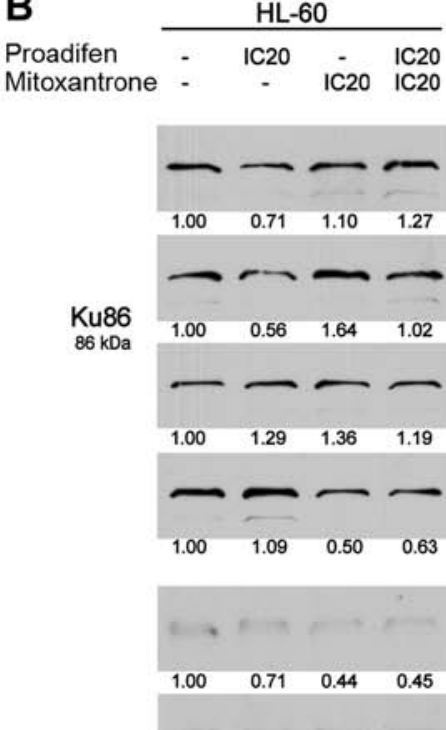

B23
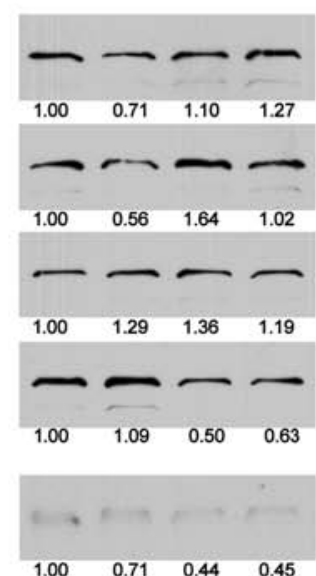

$37 \mathrm{kDa}$
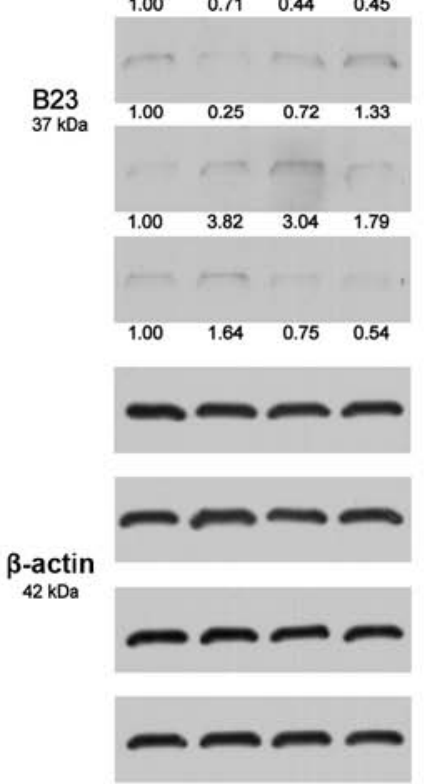
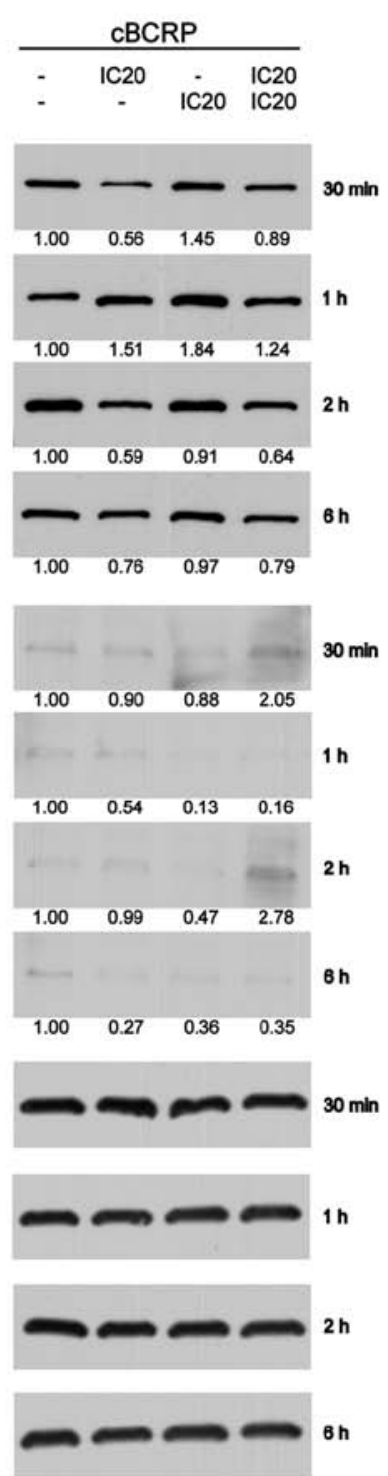

Figure 5. Changes in DNA damage and DNA repair proteins. (A) Effects of proadifen, MTX and their combination on the phosphorylation of histone H2AX (Ser 139). The results are expressed as the mean values \pm SD of at least three independent experiments. The groups treated with proadifen alone (IC ${ }_{20}$ in $H L-60$ cells equals $11.28 \mu \mathrm{M} / 2 \mathrm{~h}$ and $6.95 \mu \mathrm{M} / 24 \mathrm{~h} ; \mathrm{IC}_{20}$ in cBCRP equals $40.49 \mu \mathrm{M} / 2 \mathrm{~h}$ and $37.19 \mu \mathrm{M} / 24 \mathrm{~h}$ ) and MTX alone (IC 20 in HL-60 equals $0.029 \mu \mathrm{M} / 2$ and $24 \mathrm{~h} ; \mathrm{IC}_{20}$ in cBCRP equals $3.68 \mu \mathrm{M} / 2$ and $24 \mathrm{~h}$ ) were compared to the untreated control $\left({ }^{*} \mathrm{p}<0.05,{ }^{* *} \mathrm{p}<0.01,{ }^{* * * *} \mathrm{p}<0.001\right)$. The groups given combined treatment were compared to proadifen alone $\left({ }^{\square} \mathrm{p}<0.05,{ }^{\square} \mathrm{p}<0.01,{ }^{\square} \mathrm{p}<0.001\right)$ and MTX alone ( $\left.\mathrm{p}<0.01\right)$. (B) Effects of proadifen, MTX and their combination on protein levels of Ku86 and B23. One representative experiment of two is presented. HL-60 cells were pre-treated with $\mathrm{IC}_{20}$ of proadifen equalling 11.28 and $40.49 \mu \mathrm{M}$ in cBCRP. $\mathrm{IC}_{20}$ of MTX in HL-60 equals $0.029 \mu \mathrm{M}$; IC $\mathrm{I}_{20}$ in cBCRP equals $3.68 \mu \mathrm{M}$ at all time-points.

of hypericin-mediated photodynamic therapy (HY-PDT), most likely via the inhibition of ABC transporter activity, primarily BCRP (8). However, the exact mechanism or mechanisms engaged in the anti-proliferative and chemosensitising potential of proadifen remain unclear. Therefore, the main purpose of this study was to verify the proadifen-mediated enhancement of MTX cytotoxicity through potential BCRP inhibition using MTX-sensitive HL-60 cells and MTX-resistant ABCG2overexpressing cBCRP subclone. Another aim was to explore the mechanisms that could be involved in the anti-proliferative properties of proadifen in the cBCRP cell line.

Proadifen showed a time- and dose-dependent inhibitory effect on HL-60 and cBCRP cells, with markedly lower concentrations inhibiting the sensitive HL-60 cells. On the contrary, such a low proadifen concentration stimulated metabolic activity in resistant cBCRP cells and much higher concentrations were required for significant decreases in this parameter (data not shown). A similar effect of different proadifen concentrations in various cancer cell models was previously reported by other authors $(9,11,16)$. Consistent with previous studies $(16,17)$, we also detected dose-dependent variations in the cell cycle distribution. Whereas higher concentrations of proadifen (30.74 and $37.19 \mu \mathrm{M})$ caused an elevated accumulation of cBCRP cells in G0/G1 phase, lower concentrations $(5.51$ and $6.95 \mu \mathrm{M})$ increased the accumulation of HL-60 cells in the S-phase. These results indicate the cytostatic action of proadifen in both cell lines. However, through the determination of multiple cell death markers, we revealed that proadifen $\mathrm{IC}_{20}$ was cytotoxic only in the case of resistant cBCRP cell lines. Furthermore, in cBCRP cells, we 

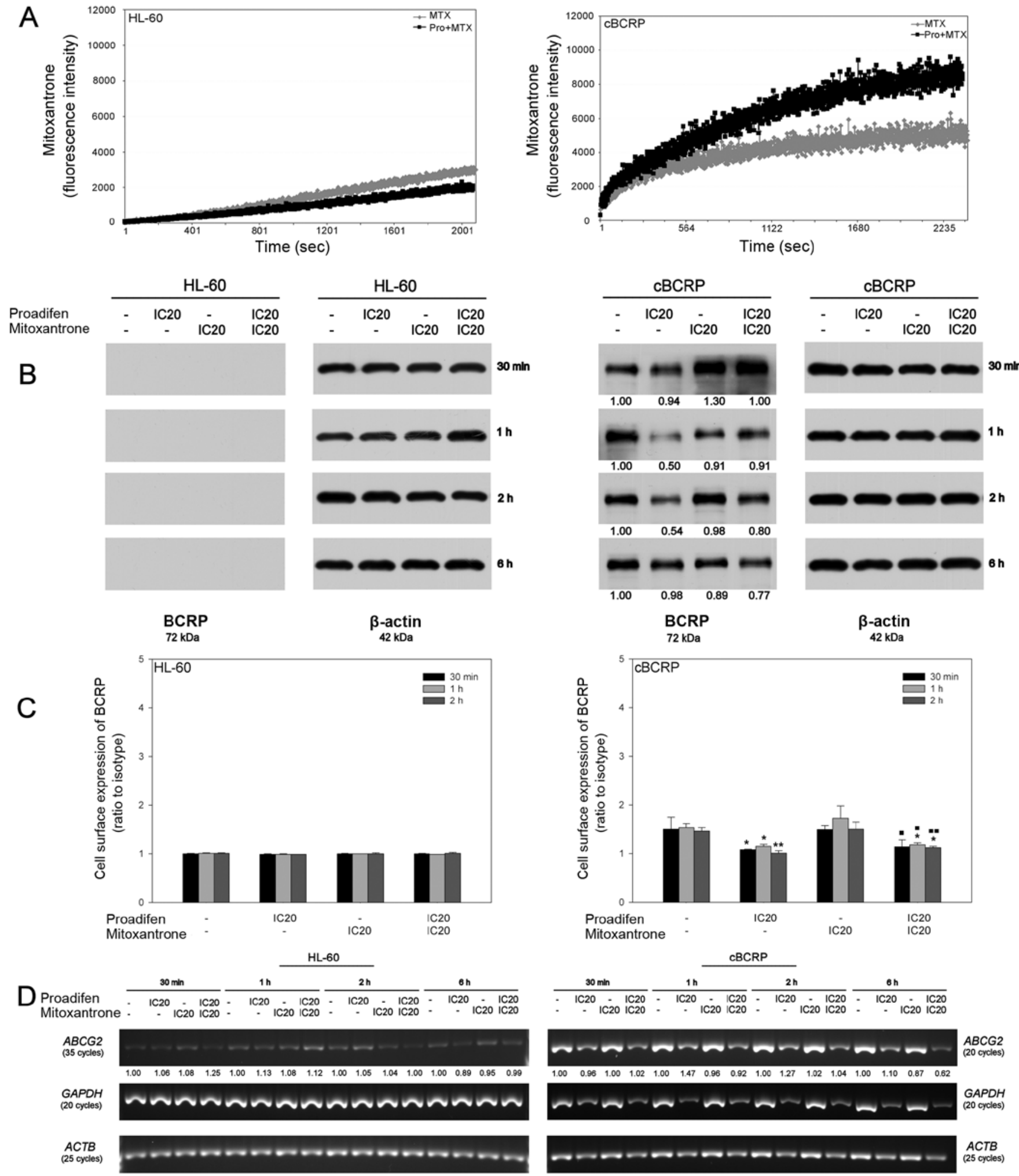

Figure 6. Effect of proadifen on BCRP expression and activity. (A) Effect of proadifen on MTX intracellular accumulation. (B) Effects of proadifen, MTX and their combination on BCRP whole cell protein levels. One representative experiment of two is presented. (C) Effects of proadifen, MTX and their combination on cell surface expression of BCRP. The results are expressed as the mean values \pm SD of at least three independent experiments. The groups treated with proadifen alone and MTX alone were compared to the untreated control $\left({ }^{*} \mathrm{p}<0.05,{ }^{* *} \mathrm{p}<0.01\right)$. The groups given combined treatment were compared to proadifen alone and MTX alone $(\mathrm{p}<0.05,-" \mathrm{p}<0.01)$. (D) Effects of proadifen, MTX and their combination on mRNA levels of BCRP. One representative experiment of two is presented. In all experiments, HL-60 cells were pre-treated with $\mathrm{IC}_{20}$ of proadifen equalling 11.28 and $40.49 \mu \mathrm{M}$ in cBCRP. IC 20 of MTX in HL-60 equals $0.029 \mu \mathrm{M} ; \mathrm{IC}_{20}$ in cBCRP equals $3.68 \mu \mathrm{M}$.

revealed decreased mRNA levels of two commonly used reference housekeeping genes, GAPDH and $A C T B$, after proadifen treatment. No such effect was observed in HL-60 cells. Since there was no change in $\beta$-actin protein levels, we assume that 

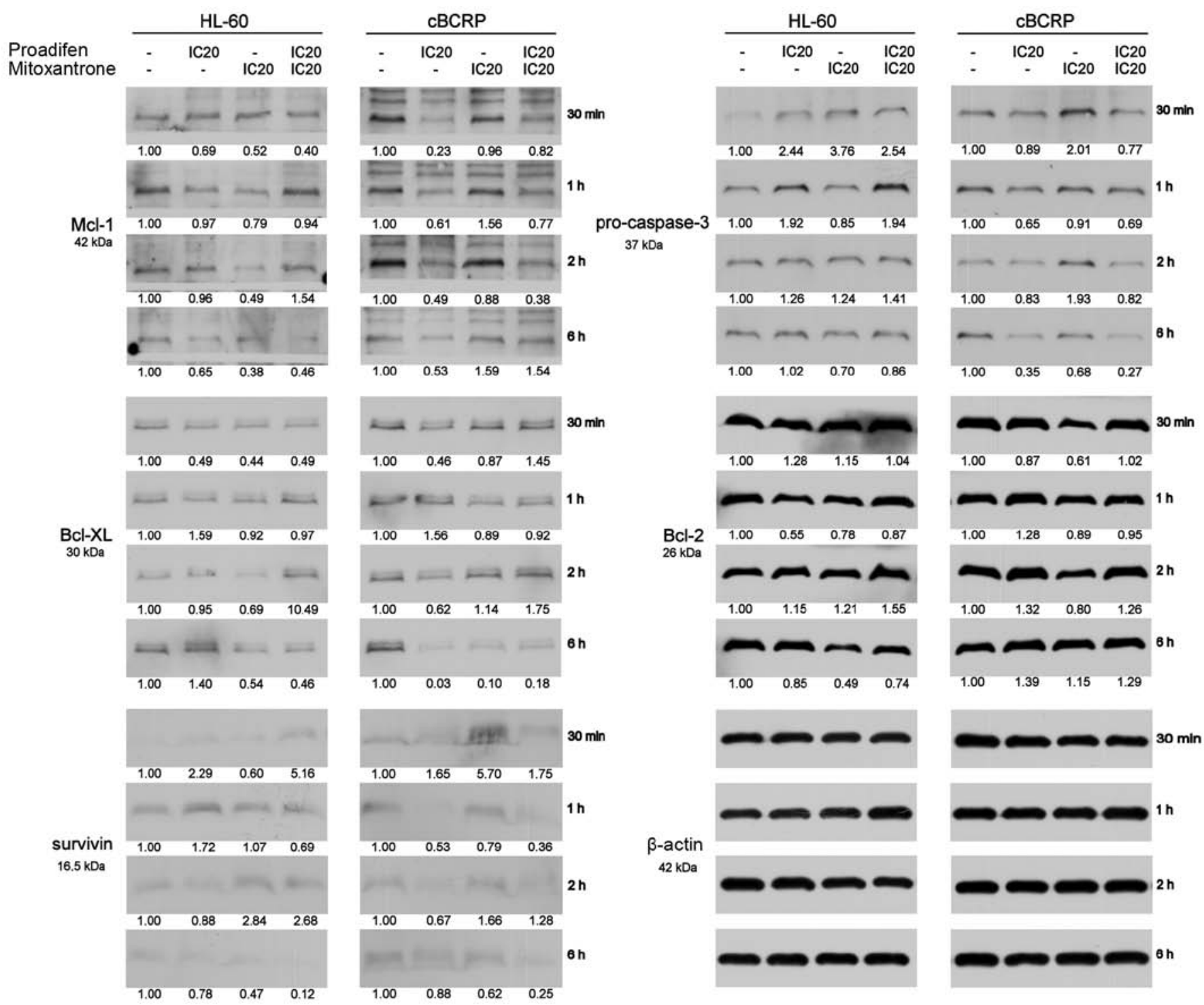

Figure 7. Effects of proadifen, MTX and their combination on the expression of anti-apoptotic proteins and activation of procaspase-3. One representative experiment of two is presented. HL-60 cells were pre-treated with $\mathrm{IC}_{20}$ of proadifen equalling 11.28 and $40.49 \mu \mathrm{M}$ in cBCRP. IC 20 of MTX in $\mathrm{HL}-60$ equals $0.029 \mu \mathrm{M} ; \mathrm{IC}_{20}$ in cBCRP equals $3.68 \mu \mathrm{M}$ at all time-points.

proadifen cytotoxicity in cBCRP cells could be related to the impairment of overall transcriptional activity or to the increase in mRNA degradation. Previously, it was found that proadifen is able to inhibit viral RNA amplification (18). On the contrary, Fernandez et al (19) indicated an inhibitory effect of proadifen on RNA degradative processes in rat liver.

Proadifen as an inhibitor of cytochrome P450 monooxygenases, along with cyclooxygenase and lipoxygenase inhibitors, could suppress the conversion of free arachidonic acid. Extensive research has focused on the role of cyclooxygenase-2 (COX-2) inhibitors in sensitising cancer cells to chemotherapy, mainly through non-specific inhibition of one or more $\mathrm{ABC}$ transporter proteins. Our previous study indicates that proadifen represents a potential agent capable of sensitising cancer cells to HY-PDT, most likely via inhibition of more than one transporter protein (8). In the present study, we showed for the first time that proadifen enhanced the sensitivity of cancer cells towards MTX treatment. Pre-treatment of MTX-resistant ABCG2-overexpressing cBCRP cells with proadifen markedly increased the cytotoxic properties of this chemotherapeutic agent. Since proadifen was able to suppress the expression of total, as well as membrane-bound BCRP protein in cBCRP cells, we suggest proadifen-mediated downregulation of the BCRP level as one of the most probable causes of its chemosensitising effect. Furthermore, $6 \mathrm{~h}$ after combined drug treatment, decrease of $A B C G 2$ mRNA level was revealed. Moreover, downregulation of BCRP by proadifen was also demonstrated by increased intracellular MTX accumulation in cBCRP cells within 45 min after MTX addition. Taken together, these results show that proadifen is not only able to inhibit BCRP expression, but also BCRP activity in the resistant cBCRP cell line. These findings are in line with our previous study (8) where proadifen suppressed hypericinmediated induction of BCRP expression at protein level, and also increased the intracellular content of hypericin in HT-29 cells. Similarly, Elahian et al (20) showed that dexamethasone, 


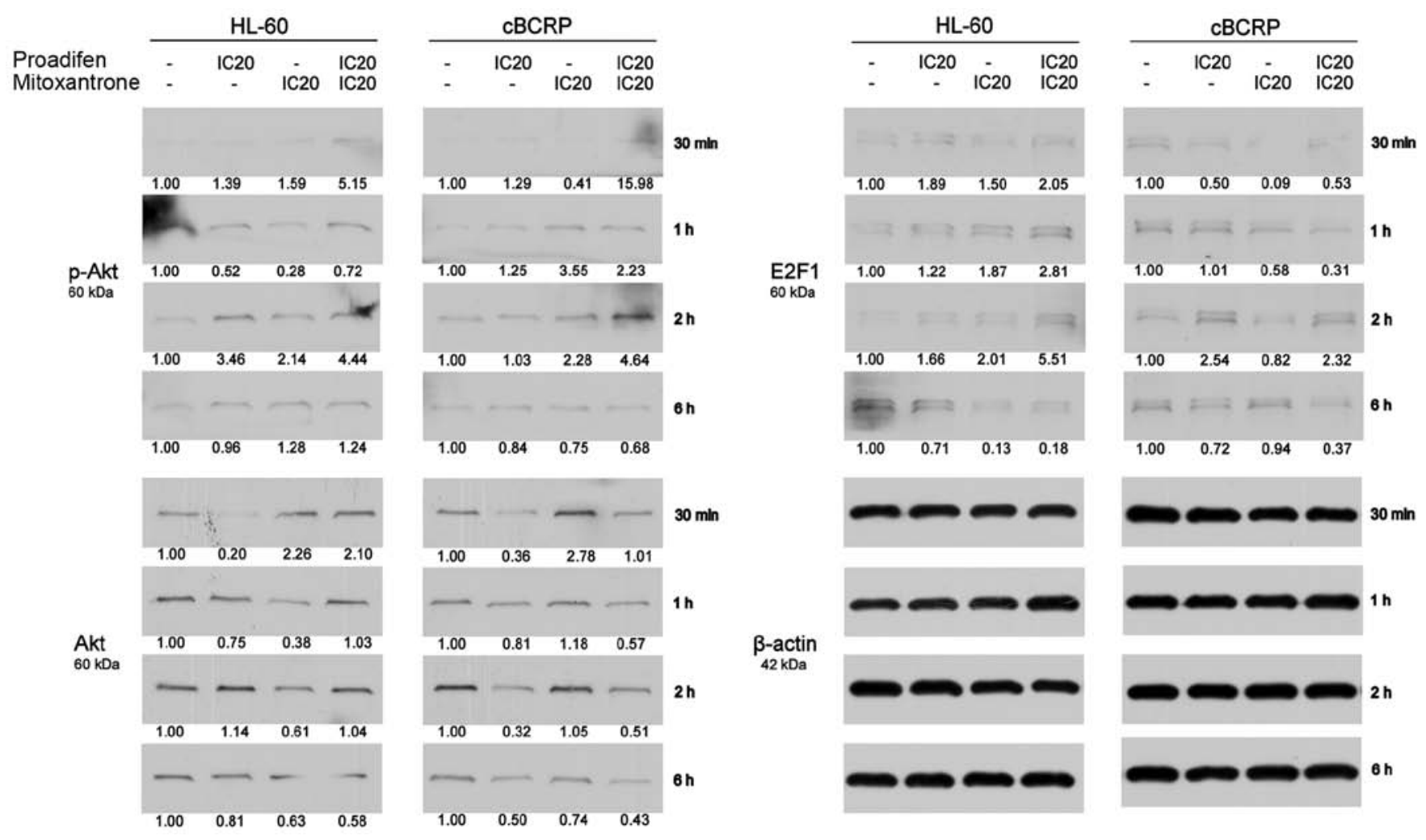

Figure 8. Effects of proadifen, MTX and their combination on the expression of proteins involved in the regulation of BCRP activity and expression. One representative experiment of two is presented. HL-60 cells were pre-treated with $\mathrm{IC}_{20}$ of proadifen equalling 11.28 and $40.49 \mu \mathrm{M}$ in cBCRP. IC 20 of MTX in HL-60 equals $0.029 \mu \mathrm{M} ; \mathrm{IC}_{20}$ in cBCRP equals $3.68 \mu \mathrm{M}$ at all time-points.

a COX-2 inhibitor, was able to enhance MTX cytotoxicity in the MTX resistant breast cancer cell line, MCF-7, through BCRP inhibition.

The underlying mechanism by which proadifen may affect BCRP expression and function is not yet fully understood. Several transcription factors and signalling pathways have been shown to regulate BCRP expression or activity (6). It was revealed that the downregulation of Akt might lead to decreased BCRP activity, but not to the changes in BCRP protein levels $(2,21)$. However, Nakanishi et al (22) demonstrated that inhibition of the Akt signalling pathway in leukemia cells affected not only the plasma membrane localisation of BCRP, but also downregulated the transporter protein levels. These studies are in contrast with our results, where we detected elevated protein levels of phosphorylated Akt, except for the latest time-point $(6 \mathrm{~h})$. We suppose that the expression and activity of BCRP in cBCRP cells is not mediated through Akt signalling. A recent study identified the transcription factor E2F1, implicated in various cellular functions, as another possible activator of BCRP expression in various human lung cancer cell lines (23). Moreover, Rosenfeld et al (23) revealed that the E2F-BCRP axis suppresses chemotherapy-induced cell death. Another important fact corresponding with our results is the attenuation of this resistance via BCRP inhibition. We found that proadifen was able to decrease the protein levels of the transcription factor E2F in cBCRP cells. The above mentioned results indicate that downregulation of E2F1 might play a role in the regulation of BCRP expression in the resistant CBCRP leukemic cells and that proadifen-mediated potentiation of MTX cytotoxicity could be related to these changes. However, further investigations will be necessary to elucidate the exact mechanisms.

Subsequently, we focused on the expression of proteins involved in the induction of apoptosis, including Bcl-2, Bcl-xL, Mcl-1 and the inhibitor of apoptosis, survivin, as well as caspase-3, a protease engaged in the execution phase of apoptosis. Interestingly, we detected slightly elevated Bcl-2 protein levels after treatment with both drugs alone and in combination, indicating Bcl-2 independent induction of apoptosis in cBCRP cells. However, proadifen alone and in combined treatment downregulated the expression of survivin, Mcl-1, and Bcl-xL and led to the activation of procaspase-3. These results are consistent with our previous study (9), where proadifen decreased the expression level of Mcl-1 and led to the activation of caspase-3 in HT-29 colorectal adenocarcinoma cells. However, it has also been determined that no effect on Bcl-xL expression existed (24,25). Mcl-1 was reported to prevent apoptosis and confer drug resistance in acute myeloid leukemia. Overexpression of Mcl-1 in HL-60 also led to crossresistance to MTX and ABT-737 (26). Downregulation of these important pro-survival factors by proadifen may contribute to the increased anti-proliferative impact of combined therapy in cBCRP cells. Several other studies showed that downregulation of survivin (27,28), Mcl-1 (29), Bcl-xL (30) and activation of caspase-3 (31) sensitised cancer cells to chemotherapy.

Since proadifen sensitised cBCRP cells to MTX-induced cell death and even affected the cytostatic action of MTX by cell cycle redistribution, we investigated the impact of proadifen on certain proteins involved in DNA damage repair. MTX, a topoisomerase II inhibitor and DNA intercalator, induces 
DSBs due to the collision of the progressing RNA polymerase with the stabilised topoisomerase II-DNA complex. Therefore, we focused on several proteins engaged in the DSBs repair. The generation of DSBs causes rapid phosphorylation of histone H2AX on Ser139 $(\gamma \mathrm{H} 2 \mathrm{AX}), \gamma \mathrm{H} 2 \mathrm{AX}$ represents an important factor in DNA damage signalling pathways (32). While proadifen had no effect on $\mathrm{H} 2 \mathrm{AX}$ phosphorylation in HL-60 cells, we observed decreased $\gamma \mathrm{H} 2 \mathrm{AX}$ expression below the untreated control level in cBCRP cells after proadifen treatment. Moreover, proadifen reverted the MTX induced expression of $\gamma \mathrm{H} 2 \mathrm{AX}$. It is well-known that nonhomologous end-joining (NHEJ) and homologous repair (HR) are the major pathways of DSBs repair. The NHEJ DSBs repair is mediated by several repair proteins, including Ku86 (XRCC5), which is the key protein involved in NHEJ (33). Recent studies demonstrated the role of nucleolar protein B23 (NPM1) in the HR pathway $(33,34)$. However, Koike et al (34) showed that only B23 phosphorylated on residue Thr199 is recruited to DSBs and plays a role in DNA repair. Our results showed that proadifen reduced the levels of repair proteins Ku86 and B23. Moreover, we determined proadifen-mediated decreases in the expression of $\gamma \mathrm{H} 2 \mathrm{AX}$, which is involved in the recruitment of the proteins necessary for the reparation process (32). These findings indicate a possible role of proadifen in DNA repair blockage, thus suppressing the rate of MTX-induced DSB reparation. However, more analyses of Thr199-phosphorylated B23 will be necessary to elucidate the role of this protein in cBCRP cells.

In conclusion, our results revealed anti-proliferative properties of proadifen in MTX-resistant human promyelocytic leukemia cells. Moreover, we demonstrated the ability of proadifen to increase the intracellular accumulation of MTX, thereby enhancing its cytotoxicity in the MTX-resistant cBCRP cell line. This effect was mediated through proadifen-mediated inhibition of BCRP activity and expression. Furthermore, our study indicates that proadifen also affects the expression levels of various anti-apoptotic proteins, as well as proteins engaged in the DNA damage repair pathways, thus enhancing chemotherapy efficacy. Taken together, based on our recent findings, as well as on previous results, we suggest that proadifen may be beneficial in combination with chemotherapy for overcoming multidrug resitance, enhancing the cytotoxicity of these drugs.

\section{Acknowledgements}

This study was supported by the Slovak Research and Development Agency under the contract no. APVV-0040-10, the Scientific Grant Agency of the Ministry of Education of the Slovak Republic under the contract no. VEGA 1/0626/11 and the Cancer Research Foundation under the contract no. 0-12-102/0001-00. The authors are very grateful to Viera Balážová for the assistance with technical procedures.

\section{References}

1. Nakanishi T, Chumsri S, Khakpour N, Brodie AH, LeylandJones B, Hamburger AW, Ross DD and Burger AM: Side-population cells in luminal-type breast cancer have tumour-initiating cell properties, and are regulated by HER 2 expression and signalling. Br J Cancer 102: 815-826, 2010.
2. Hu C, Li H, Li J, Zhu Z, Yin S, Hao X, Yao M, Zheng S and Gu J: Analysis of ABCG2 expression and side population identifies intrinsic drug efflux in the HCC cell line MHCC-97L and its modulation by Akt signaling. Carcinogenesis 29: 2289-2297, 2008.

3. Hu L, McArthur C and Jaffe RB: Ovarian cancer stem-like side-population cells are tumourigenic and chemoresistant. Br J Cancer 102: 1276-1283, 2010.

4. Salcido CD, Larochelle A, Taylor BJ, Dunbar CE and Varticovski L: Molecular characterisation of side population cells with cancer stem cell-like characteristics in small-cell lung cancer. Br J Cancer 102: 1636-1644, 2010

5. Liu T, Xu F, Du X, Lai D, Liu T, Zhao Y, Huang Q, Jiang L, Huang W, Cheng W, et al: Establishment and characterization of multi-drug resistant, prostate carcinoma-initiating stem-like cells from human prostate cancer cell lines 22RV1. Mol Cell Biochem 340: 265-273, 2010.

6. Natarajan K, Xie Y, Baer MR and Ross DD: Role of breast cancer resistance protein (BCRP/ABCG2) in cancer drug resistance. Biochem Pharmacol 83: 1084-1103, 2012.

7. Diah SK, Smitherman PK, Aldridge J, Volk EL, Schneider E, Townsend AJ and Morrow CS: Resistance to mitoxantrone in multidrug-resistant MCF7 breast cancer cells: Evaluation of mitoxantrone transport and the role of multidrug resistance protein family proteins. Cancer Res 61: 5461-5467, 2001.

8. Jendzelovský R, Mikes J, Koval' J, Soucek K, Procházková J, Kello M, Sacková V, Hofmanová J, Kozubík A and Fedorocko P: Drug efflux transporters, MRP1 and BCRP, affect the outcome of hypericin-mediated photodynamic therapy in HT-29 adenocarcinoma cells. Photochem Photobiol Sci 8: 1716-1723, 2009.

9. Jendželovský R, Koval J, Mikeš J, Papčová Z, Plšíková J and Fedoročko P: Inhibition of GSK-3 $\beta$ reverses the pro-apoptotic effect of proadifen (SKF-525A) in HT-29 colon adenocarcinoma cells. Toxicol In Vitro 26: 775-782, 2012.

10. Ozvegy-Laczka C, Hegedus T, Várady G, Ujhelly O, Schuetz JD, Váradi A, Kéri G, Orfi L, Német K and Sarkadi B: High-affinity interaction of tyrosine kinase inhibitors with the ABCG2 multidrug transporter. Mol Pharmacol 65: 1485-1495, 2004.

11. Kleban J, Mikes J, Szilárdiová B, Koval J, Sacková V, Solár P, Horváth V, Hofmanová J, Kozubík A and Fedorocko P: Modulation of hypericin photodynamic therapy by pretreatment with 12 various inhibitors of arachidonic acid metabolism in colon adenocarcinoma HT-29 cells. Photochem Photobiol 83: 1174-1185, 2007.

12. Chou TC and Talalay P: Quantitative analysis of dose-effect relationships: The combined effects of multiple drugs or enzyme inhibitors. Adv Enzyme Regul 22: 27-55, 1984.

13. Jendželovská Z, Jendželovský R, Hil'ovská L, Koval' J, Mikeš J and Fedoročko P: Single pre-treatment with hypericin, a St. John's wort secondary metabolite, attenuates cisplatin- and mitoxantrone-induced cell death in A2780, A2780cis and HL-60 cells. Toxicol In Vitro 28: 1259-1273, 2014.

14. Kretschy N, Teichmann M, Kopf S, Atanasov AG, Saiko P, Vonach C, Viola K, Giessrigl B, Huttary N, Raab I, et al: In vitro inhibition of breast cancer spheroid-induced lymphendothelial defects resembling intravasation into the lymphatic vasculature by acetohexamide, isoxsuprine, nifedipin and proadifen. $\mathrm{Br} \mathrm{J}$ Cancer 108: 570-578, 2013.

15. Spitzmaul G, Gumilar F, Dilger JP and Bouzat C: The local anaesthetics proadifen and adiphenine inhibit nicotinic receptors by different molecular mechanisms. Br J Pharmacol 157: 804-817, 2009.

16. Hoferová Z, Soucek K, Hofmanová J, Hofer M, Chramostová K, Fedorocko $\mathrm{P}$ and Kozubik A: In vitro proliferation of fibrosarcoma cells depends on intact functions of lipoxygenases and cytochrome P-450-monooxygenase. Cancer Invest 22: 234-247, 2004 .

17. Hofmanová J, Soucek K, Dusek L, Netíková J and Kozubík A: Inhibition of the cytochrome P-450 modulates all-trans-retinoic acid-induced differentiation and apoptosis of HL-60 cells. Cancer Detect Prev 24: 325-342, 2000.

18. Huang YC and Han YS: Determining anti-betanodavirus compounds through a GF-1 cell-based screening platform. Antiviral Res 105: 47-53, 2014.

19. Fernández G, Villarruel MC, Bernacchi A, de Castro CR and Castro JA: Effects of repeated administration of rat 2-diethylaminoethyl-2-2-diphenylvalerate-HCI (SKF 525 A) on liver. Toxicology 20: 185-193, 1981.

20. Elahian F, Kalalinia F and Behravan J: Evaluation of indomethacin and dexamethasone effects on BCRP-mediated drug resistance in MCF-7 parental and resistant cell lines. Drug Chem Toxicol 33: 113-119, 2010. 
21. Chu TS, Chen JS, Lopez JP, Pardo FS, Aguilera J and Ongkeko WM: Imatinib-mediated inactivation of Akt regulates ABCG2 function in head and neck squamous cell carcinoma. Arch Otolaryngol Head Neck Surg 134: 979-984, 2008.

22. Nakanishi T, Shiozawa K, Hassel BA and Ross DD: Complex interaction of BCRP/ABCG2 and imatinib in BCR-ABLexpressing cells: BCRP-mediated resistance to imatinib is attenuated by imatinib-induced reduction of BCRP expression. Blood 108: 678-684, 2006.

23. Rosenfeldt MT, Bell LA, Long JS, O'Prey J, Nixon C, Roberts F, Dufès C and Ryan KM: E2F1 drives chemotherapeutic drug resistance via ABCG2. Oncogene 33: 4164-4172, 2014.

24. Breitenbuecher F, Markova B, Kasper S, Carius B, Stauder T, Böhmer FD, Masson K, Rönnstrand L, Huber C, Kindler T, et al: A novel molecular mechanism of primary resistance to FLT3kinase inhibitors in AML. Blood 113: 4063-4073, 2009.

25. Glaser SP, Lee EF, Trounson E, Bouillet P, Wei A, Fairlie WD, Izon DJ, Zuber J, Rappaport AR, Herold MJ, et al: Anti-apoptotic Mcl-1 is essential for the development and sustained growth of acute myeloid leukemia. Genes Dev 26: 120-125, 2012.

26. Hermanson DL, Das SG, Li Y and Xing C: Overexpression of Mcl-1 confers multidrug resistance, whereas topoisomerase II $\beta$ downregulation introduces mitoxantrone-specific drug resistance in acute myeloid leukemia. Mol Pharmacol 84: 236-243, 2013.

27. Fuessel S, Herrmann J, Ning S, Kotzsch M, Kraemer K, Schmidt U, Hakenberg OW, Wirth MP and Meye A: Chemosensitization of bladder cancer cells by survivin-directed antisense oligodeoxynucleotides and siRNA. Cancer Lett 232: 243-254, 2006.
28. Dong H, Liu G, Jiang B, Guo J, Tao G, Yiu W, Zhou J and Li G: The effects of aspirin plus cisplatin on SGC7901/CDDP cells in vitro. Biomed Rep 2: 344-348, 2014.

29. Li G, Zhang S, Fang H, Yan B, Zhao Y, Feng L, Ma X and Ye X: Aspirin overcomes Navitoclax-resistance in hepatocellular carcinoma cells through suppression of Mcl-1. Biochem Biophys Res Commun 434: 809-814, 2013.

30. Bank A, Yu J and Zhang L: NSAIDs downregulate Bcl-X(L) and dissociate BAX and Bcl-X(L) to induce apoptosis in colon cancer cells. Nutr Cancer 60 (Suppl 1): S98-S103, 2008.

31. Zhang DQ, Guo Q, Zhu JH and Chen WC: Increase of cyclooxygenase-2 inhibition with celecoxib combined with 5-FU enhances tumor cell apoptosis and antitumor efficacy in a subcutaneous implantation tumor model of human colon cancer. World J Surg Oncol 11: 16, 2013.

32. Paull TT, Rogakou EP, Yamazaki V, Kirchgessner CU, Gellert M and Bonner WM: A critical role for histone H2AX in recruitment of repair factors to nuclear foci after DNA damage. Curr Biol 10: 886-895, 2000

33. Kalra RS and Bapat SA: Enhanced levels of double-strand DNA break repair proteins protect ovarian cancer cells against genotoxic stress-induced apoptosis. J Ovarian Res 6: 66, 2013.

34. Koike A, Nishikawa H, Wu W, Okada Y, Venkitaraman AR and Ohta T: Recruitment of phosphorylated NPM1 to sites of DNA damage through RNF8-dependent ubiquitin conjugates. Cancer Res 70: 6746-6756, 2010. 